https://doi.org/10.5194/bg-2022-30

Preprint. Discussion started: 1 March 2022

(C) Author(s) 2022. CC BY 4.0 License.

\title{
Tracing the source of nitrate enriched in a forested stream during storm events
}

\author{
Weitian Ding ${ }^{1}$, Urumu Tsunogai ${ }^{1}$, Fumiko Nakagawa ${ }^{1}$, Takashi Sambuichi ${ }^{1}$, Hiroyuki \\ Sase $^{2}$, Masayuki Morohashi ${ }^{2}$, Hiroki Yotsuyanagi ${ }^{2}$ \\ ${ }^{1}$ Graduate School of Environmental Studies, Nagoya University, Furo-cho, Chikusa- \\ ku, Nagoya 464-8601, Japan \\ ${ }^{2}$ Asia Center for Air Pollution Research, 1182 Sowa, Nishi-ku, Niigata-shi, Niigata 950- \\ 2144, Japan \\ Corresponding author: Weitian Ding, Email: dingweitian@nagoya-u.jp
}


1 Abstract

To clarify the source of nitrate increased during storm events in temperate forested streams, we monitored temporal variation in the concentrations and stable isotopic compositions including $\Delta^{17} \mathrm{O}$ of stream nitrate in a forested catchment (KJ catchment, Japan) during three storm events I, II, and III. The stream showed significant temporal variation in nitrate concentration, from $24.7 \mu \mathrm{M}$ to $122.6 \mu \mathrm{M}$, from $28.7 \mu \mathrm{M}$ to 134.1 $\mu \mathrm{M}$, and from $46.6 \mu \mathrm{M}$ to $114.5 \mu \mathrm{M}$ during the storm events I, II, and III, respectively. On the other hand, the isotopic compositions $\left(\delta^{15} \mathrm{~N}, \delta^{18} \mathrm{O}\right.$, and $\left.\Delta^{17} \mathrm{O}\right)$ of stream nitrate showed a decrease in accordance with the increase in the stream nitrate concentration, from $+2.5 \%$ to $-0.1 \%$, from $+3.0 \%$ to $-0.5 \%$, and from $+3.5 \%$ to $-0.1 \%$ for $\delta^{15} \mathrm{~N}$, from $+3.1 \%$ to $-3.4 \%$, from $+2.9 \%$ to $-2.5 \%$, and from $+2.1 \%$ to $-2.3 \%$ for $\delta^{18} \mathrm{O}$, and from $+1.6 \%$ to $+0.3 \%$, from $+1.4 \%$ to $+0.3 \%$, and from $+1.2 \%$ to $+0.5 \%$ for $\Delta^{17} \mathrm{O}$ during the storm events I, II, and III, respectively. Besides, we found strong linear relationships between the isotopic compositions $\left(\delta^{15} \mathrm{~N}, \delta^{18} \mathrm{O}\right.$, and $\left.\Delta^{17} \mathrm{O}\right)$ of stream nitrate and the reciprocal of stream nitrate concentrations during each storm event, implying that the temporal variation in the stream nitrate can be explained by simple mixing between two distinctive endmembers of nitrate having different isotopic compositions. Furthermore, we found that both concentrations and the isotopic compositions of soil nitrate obtained in the riparian zone of the stream were plotted on the nitrate-enriched extension of the linear relationship. We conclude that the soil nitrate in the riparian zone was responsible for the increase in stream nitrate during the storm 
events. In addition, we found that the concentration of unprocessed atmospheric nitrate in the stream was stable at $1.6 \pm 0.4 \mu \mathrm{M}, 1.8 \pm 0.4 \mu \mathrm{M}$, and $2.1 \pm 0.4 \mu \mathrm{M}$ during the storm events I, II, and III, respectively, irrespective to the significant variations in the total nitrate concentration. We conclude that the storm events have little impacts on the concentration of unprocessed atmospheric nitrate in the stream and thus the annual export flux of unprocessed atmospheric nitrate relative to the annual deposition flux can be a robust index to evaluate nitrogen saturation in forested catchments, irrespective to the variation in the number of storm events and/or the variation in the elapsed time from storm events to sampling.

\section{Introduction}

Nitrate is a representative nitrogenous nutrient in biosphere. Traditionally, forested ecosystems have been considered nitrogen limited (Vitousek and Howarth, 1991). Due to the elevated loading of nitrogen through atmospheric deposition, however, some forested ecosystems become nitrogen saturated (Aber et al., 1989), from which elevated levels of nitrate are exported (Mitchell et al., 1997; Peterjohn et al., 1996). In addition, sudden increase in the concentration of nitrate in response to storm events has been reported in forested streams worldwide (Aguilera and Melack, 2018; Creed et al., 1996; Kamisako et al., 2008; McHale et al., 2002), which further enhanced nitrate export from forested ecosystems.

Such excessive leaching of nitrate from forested catchment degrades water quality 

and cause eutrophication in downstream areas (Galloway et al., 2003; Paerl and Huisman, 2009). Thus, tracing the source of nitrate increase during storm events in forested streams is important for sustainable forest management, especially for those nitrogen-saturated forested ecosystems.

As for the source of nitrate that was added to stream during storm events, either of the two possible sources have been assumed in past studies; (1) atmospheric nitrate $\left(\mathrm{NO}_{3}{ }^{-}\right.$atm $)$in rainwater originally and being supplied directly to stream water though the overland flow (Kaushal et al., 2011; Sebestyen et al., 2014), and (2) soil nitrate originally and being supplied to stream water by the flushing effects on soils (Creed et al., 1996; Ocampo et al., 2006). Nevertheless, monitoring the variation in nitrate concentration, it is difficult to clarify the primary source of nitrate that increases during storm events.

The natural stable isotopic composition of nitrate has been widely applied to clarify the sources of nitrate in natural freshwater systems (Burns and Kendall, 2002; Durka et al., 1994; Kendall et al., 2007). In particular, triple oxygen isotopic compositions of nitrate $\left(\Delta^{17} \mathrm{O}\right)$ have been used in recent days as a conservative tracer of $\mathrm{NO}_{3}^{-}{ }^{-}$atm deposited onto a forested catchment (Inoue et al., 2021; Michalski et al., 2004; Nakagawa et al., 2018; Tsunogai et al., 2014), showing distinctively different $\Delta^{17} \mathrm{O}$ from that of remineralized nitrate $\left(\mathrm{NO}_{3}{ }^{-}\right.$re $)$, derived from organic nitrogen through general chemical reactions, including microbial $\mathrm{N}$ mineralization and microbial nitrification. While $\mathrm{NO}_{3}{ }^{-}$re, the oxygen atoms of which are derived from either terrestrial $\mathrm{O}_{2}$ or $\mathrm{H}_{2} \mathrm{O}$ 
64 through microbial processing (i.e., nitrification), always shows the relation close to the

“mass-dependent" relative relation between ${ }^{17} \mathrm{O} /{ }^{16} \mathrm{O}$ ratios and ${ }^{18} \mathrm{O} /{ }^{16} \mathrm{O}$ ratios; $\mathrm{NO}_{3}{ }^{-}$atm displays an anomalous enrichment in ${ }^{17} \mathrm{O}$ reflecting oxygen atom transfers from atmospheric ozone $\left(\mathrm{O}_{3}\right)$ during the conversion of $\mathrm{NO}_{\mathrm{X}}$ to $\mathrm{NO}_{3}{ }^{-}$atm (Alexander et al., 2009; Michalski et al., 2003; Morin et al., 2011; Nelson et al., 2018). As a result, the $\Delta^{17} \mathrm{O}$ signature defined by the following equation (Kaiser et al., 2007) enables us to distinguish $\mathrm{NO}_{3}{ }^{-}{ }^{-}{ }^{-}\left(\Delta^{17} \mathrm{O}>0\right)$ from $\mathrm{NO}_{3}{ }^{-}{ }^{-}\left(\Delta^{17} \mathrm{O}=0\right)$ :

$\Delta^{17} \mathrm{O}=\frac{1+\delta^{17} \mathrm{O}}{\left(1+\delta^{18} \mathrm{O}\right)^{\beta}}-1$

where the constant $\beta$ is 0.5279 (Kaiser et al., 2007), $\delta^{18} \mathrm{O}=R_{\text {sample }} / R_{\text {standard }}-1$ and $R$ is the ${ }^{18} \mathrm{O} /{ }^{16} \mathrm{O}$ ratio (or the ${ }^{17} \mathrm{O} /{ }^{16} \mathrm{O}$ ratio in the case of $\delta^{17} \mathrm{O}$ or the ${ }^{15} \mathrm{~N} /{ }^{14} \mathrm{~N}$ ratio in the case of $\delta^{15} \mathrm{~N}$ ) of the sample and each standard reference material. In addition, $\Delta^{17} \mathrm{O}$ is almost stable during "mass-dependent" isotope fractionation processes within terrestrial ecosystems. Therefore, while the $\delta^{15} \mathrm{~N}$ or $\delta^{18} \mathrm{O}$ signature of $\mathrm{NO}_{3}{ }^{-}$atm can be overprinted by the biological processes subsequent to deposition, $\Delta^{17} \mathrm{O}$ can be used as a robust tracer of unprocessed $\mathrm{NO}_{3}{ }^{-}$atm to reflect its accurate mole fraction within total $\mathrm{NO}_{3}{ }^{-}$, regardless of the progress of the partial metabolism (partial removal of nitrate through denitrification and assimilation) subsequent to deposition (Michalski et al., 2004; Nakagawa et al., 2013, 2018; Tsunogai et al., 2011, 2014, 2018).

In this study, by using the stable isotopes including $\Delta^{17} \mathrm{O}$ of nitrate as tracers, we clarified (1) the source of nitrate in a forested stream that was added during storm events, and (2) the temporal variation in the concentration of $\mathrm{NO}_{3}{ }^{-}$atm in response to storm 
events. In addition, the impacts of storm events on the index of nitrogen saturation lately proposed by Nakagawa et al. (2018) were discussed.

\section{Methods}

2.1 Study site

As for the studying field to trace the source of stream nitrate during storm events, we chose Kajikawa forested catchment (KJ catchment) in Japan, in which several past studies had been done to clarify the temporal variation in the concentration of stream nitrate and the status of nitrogen saturation (Kamisako et al., 2008; Nakagawa et al., 2018; Sase et al., 2021). This is a small, forested catchment (3.84 ha) located in the northern part of Shibata City, Niigata Prefecture, along the coast of Sea of Japan (Fig. 1a). The KJ catchment predominantly slopes towards the west-northwest, with a mean slope of $36^{\circ}$, and the elevation ranges from 60 to $170 \mathrm{~m}$ above sea level (Fig. $\left.1 \mathrm{~b}\right)$. The catchment is fully covered by Japanese cedars (Cryptomeria japonica D. Don) that were approximately 46 years old in 2018 (Sase et al., 2021). The parent material is granodiorite and brown forest soils (Cambisols) have developed in this area (Kamisako et al., 2008; Sase et al., 2008). The lowest, highest, and mean monthly temperatures recorded at the nearest meteorological station (Nakajo station) were $1.0{ }^{\circ} \mathrm{C}$ (in February), $27.9^{\circ} \mathrm{C}$ (in August), and $14.5^{\circ} \mathrm{C}$, respectively, from $2017 / 5$ to $2020 / 3$. The annual mean precipitation was around $2500 \mathrm{~mm}$, approximately $17 \%$ of which occurred during spring (from March to May), approximately 20\% during summer (from June to August), 
approximately $28 \%$ during fall (from September to November), and approximately $35 \%$ during winter (from December to February). The catchment usually experiences snowfall from late December to March.

From 2003 to 2005, Kamisako et al. (2008) determined temporal variation in the concentration of $\mathrm{Ca}^{2+}, \mathrm{Mg}^{2+}, \mathrm{Cl}^{-}$, and $\mathrm{NO}_{3}{ }^{-}$eluted from the catchment via a stream at intervals of 1 to 3 hour for 2 to 3 days on each and found that significant increase in the stream nitrate concentration during storm events, from less than $30 \mu \mathrm{M}$ to more than $120 \mu \mathrm{M}$. On the basis of the observed nitrate enrichment in the stream water, they concluded that atmospheric nitrogen inputs exceeded the biological demand at the catchment and proposed that the $\mathrm{KJ}$ catchment was under nitrogen saturation. Nakagawa et al. (2018) determined temporal variation in the concentrations and stable isotopic compositions $\left(\delta^{15} \mathrm{~N}, \delta^{18} \mathrm{O}\right.$, and $\left.\Delta^{17} \mathrm{O}\right)$ of both stream nitrate and soil nitrate for two years (from 2012/12 to 2014/12) and concluded that nitrate in the groundwater of the catchment was the major source of nitrate in the stream water during the base flow periods. Additionally, the export flux of unprocessed atmospheric nitrate relative to the deposition flux of atmospheric nitrate in KJ catchment $\left(\mathrm{M}_{\mathrm{atm}} / \mathrm{D}_{\text {atm }}\right)$ was larger $(9.4 \%)$ than the other catchment they studied simultaneously (6.5\% and $2.6 \%$ respectively) and proposed that the $\mathrm{M}_{\mathrm{atm}} / \mathrm{D}_{\mathrm{atm}}$ ration can be used as the index of nitrogen saturation. Moreover, Sase et al. (2021) reported the nitrate concentration of the stream has been increasing in recent years, which implies that nitrogen saturation is still ongoing in the forest. 


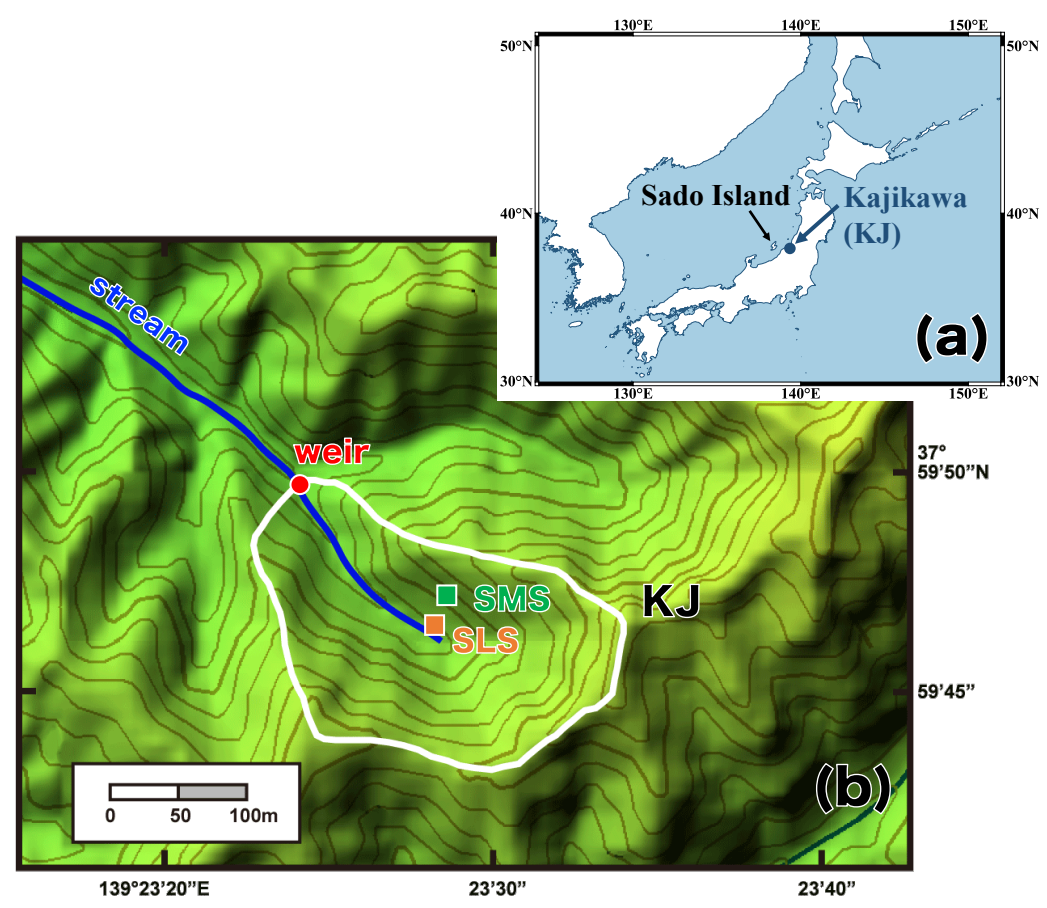

129 Figure. 1 A map showing the locations of the studied Kajikawa (KJ) catchment in Japan

(a) and a colored altitude map of the KJ catchment (b) (modified after Nakagawa et al.

131 2018). The white line denotes the whole catchment area, and the red circle denotes the position of the weir where the stream water was sampled. The orange (SLS) and green (SMS) circles denote the sampling stations of soil water in the riparian and upland zone, respectively, in the past study (Nakagawa et al., 2018). the catchment (Fig. 1b), where the discharge rates were determined. The weather 
139 information including the precipitation monitored by Japan Meteorological Agency at

140 the nearest station of KJ catchment (Nakajo station; 38 $04^{\prime} 60^{\prime \prime} \mathrm{N}, 139^{\circ} 23^{\prime} 30^{\prime \prime} \mathrm{E}$ ) was

141 used for that in the KJ catchment. Because the accumulated snow was not monitored

142 in Nakajo station, however, those monitored at the Niigata station $\left(37^{\circ} 53^{\prime} 60^{\prime \prime} \mathrm{N}\right.$,

$143 \quad 139^{\circ} 01^{\prime} 10^{\prime \prime}$ E) was used instead.

In this study, the concentrations and stable isotopic compositions $\left(\delta^{15} \mathrm{~N}, \delta^{18} \mathrm{O}\right.$, and $\Delta^{17} \mathrm{O}$ ) of stream nitrate eluted from the $\mathrm{KJ}$ catchment were monitored every month additionally for more than 2 years (routine observation). Additionally, during storm events, the same parameters were monitored every hour for 1 day (intensive observation). Stream water was sampled at the weir located on the outlet of the KJ catchment (Fig. 1b). Routine observation was performed manually using bottles at the weir approximately once a month from $2017 / 5$ to $2020 / 3$. Intensive observation was conducted during the three storm events I, II, and III $(2019 / 8 / 22,2019 / 10 / 12$, and 2020/9/13, respectively), where the water samples were collected at intervals of 1 hour over 24 hours using an automatic water sampler (SIGMA 900, Hach, USA). In this study, 0.5 or $2 \mathrm{~L}$ polyethylene bottles washed using chemical detergents were rinsed at least three times using deionized water and dried in the laboratory before being used to store the water samples. 


\subsection{Analysis}

Samples of stream water for the routine observation were transported to the laboratory within 1 hour after being collected manually. Samples for the intensive observation were transported within 1 or 2 weeks after completion of the automatic sampling. All samples were passed through a membrane filter (pore size $0.45 \mu \mathrm{m}$ ) and stored in a refrigerator $\left(4^{\circ} \mathrm{C}\right)$ prior to their chemical analysis.

The concentrations of nitrate were measured by ion chromatography (DX-500; Dionex Inc., USA). To determine the stable isotopic compositions of nitrate in the stream water samples, nitrate in each sample was chemically converted to $\mathrm{N}_{2} \mathrm{O}$ using a method originally developed to determine the ${ }^{15} \mathrm{~N} /{ }^{14} \mathrm{~N}$ and ${ }^{18} \mathrm{O} /{ }^{16} \mathrm{O}$ ratios of seawater and freshwater nitrate (McIlvin and Altabet, 2005) that was later modified (Konno et al., 2010; Tsunogai et al., 2011; Yamazaki et al., 2011). In brief, $11 \mathrm{~mL}$ of each sample solution was pipetted into a vial with a septum cap. Then, $0.5 \mathrm{~g}$ of spongy cadmium was added, followed by $150 \mu \mathrm{L}$ of a $1 \mathrm{M} \mathrm{NaHCO}_{3}$ solution. The sample was then shaken for $18-24 \mathrm{~h}$ at a rate of 2 cycles $\mathrm{s}^{-1}$. Then, the sample solution $(10 \mathrm{~mL})$ was decanted into a different vial with a septum cap. After purging the solution using high-purity helium, $0.4 \mathrm{~mL}$ of an azide-acetic acid buffer, which had also been purged using highpurity helium, was added. After $45 \mathrm{~min}$, the solution was alkalinized by adding $0.2 \mathrm{~mL}$ of $6 \mathrm{M} \mathrm{NaOH}$.

Then, the stable isotopic compositions $\left(\delta^{15} \mathrm{~N}, \delta^{18} \mathrm{O}\right.$, and $\left.\Delta^{17} \mathrm{O}\right)$ of the $\mathrm{N}_{2} \mathrm{O}$ in each vial were determined using the continuous-flow isotope ratio mass spectrometry (CF-IRMS) 
system at Nagoya University. The analytical procedures performed using the CF-IRMS system were the same as those detailed in previous studies (Hirota et al., 2010; Komatsu et al., 2008). The obtained values of $\delta^{15} \mathrm{~N}, \delta^{18} \mathrm{O}$, and $\Delta^{17} \mathrm{O}$ for the $\mathrm{N}_{2} \mathrm{O}$ derived from the nitrate in each sample were compared with those derived from our local laboratory nitrate standards to calibrate the values of the sample nitrate to an international scale and to correct for both isotope fractionation during the chemical conversion to $\mathrm{N}_{2} \mathrm{O}$ and the progress of oxygen isotope exchange between the nitrate derived reaction intermediate and water (ca. $20 \%$ ). The local laboratory nitrate standards used for the calibration had been calibrated using the internationally distributed isotope reference materials (USGS-34 and USGS-35). In this study, we adopted the internal standard method (Nakagawa et al., 2013, 2018; Tsunogai et al., 2014) to calibrate the stable isotopic compositions of sample nitrate. In order to calibrate the differences in $\delta^{18} \mathrm{O}$ of $\mathrm{H}_{2} \mathrm{O}$ between the samples and those our local laboratory nitrate standards were added for calibration, the $\delta^{18} \mathrm{O}$ values of $\mathrm{H}_{2} \mathrm{O}$ in the samples were analyzed as well (Tsunogai et al., 2010, 2011, 2014).

To determine whether the conversion rate from nitrate to $\mathrm{N}_{2} \mathrm{O}$ was sufficient, the concentration of nitrate in the samples was determined each time we analyzed the isotopic composition using CF-IRMS based on the $\mathrm{N}_{2} \mathrm{O}^{+}$or $\mathrm{O}_{2}{ }^{+}$outputs. We adopted the $\delta^{15} \mathrm{~N}, \delta^{18} \mathrm{O}$, and $\Delta^{17} \mathrm{O}$ values only when the concentration measured via CF-IRMS correlated with the concentration measured via ion chromatography prior to isotope analysis within a difference of $10 \%$. 

better than $\pm 0.2 \%$ for $\delta^{15} \mathrm{~N}, \pm 0.3 \%$ for $\delta^{18} \mathrm{O}$, and $\pm 0.1 \%$ for $\Delta^{17} \mathrm{O}$. because the chemical method also converts $\mathrm{NO}_{2}{ }^{-}$to $\mathrm{N}_{2} \mathrm{O}$ (McIlvin and Altabet, 2005). Therefore, it is sometimes necessary to remove $\mathrm{NO}_{2}^{-}$prior to converting nitrate to $\mathrm{N}_{2} \mathrm{O}$. However, in this study, all the stream and soil water samples analyzed for stable isotopic composition had $\mathrm{NO}_{2}^{-}$concentrations lower than the detection limit $(0.05 \mu \mathrm{M})$. Because the minimum nitrate concentration in the samples was $24.7 \mu \mathrm{M}$ in this study, the ratios of $\mathrm{NO}_{2}{ }^{-}$to nitrate in the samples must be less than $0.2 \%$. Thus, we skipped the processes for removing $\mathrm{NO}_{2}^{-}$. $\mathrm{NO}_{3}{ }^{-}$atm $\left(\left[\mathrm{NO}_{3}{ }^{-}\right.\right.$atm $\left.]\right)$in the stream water samples by applying Eq. (2):

$219\left[\mathrm{NO}_{3}{ }^{-}{ }^{-}{ }^{-}\right] /\left[\mathrm{NO}_{3}{ }^{-}\right]=\Delta^{17} \mathrm{O} / \Delta^{17} \mathrm{O}_{\text {atm }}$ where $\left[\mathrm{NO}_{3}{ }^{-}\right.$atm $]$and $\left[\mathrm{NO}_{3}{ }^{-}\right]$denote the concentration of $\mathrm{NO}_{3}{ }^{-}$atm and nitrate (total) in

221 each water sample, respectively, and $\Delta^{17} \mathrm{O}_{\mathrm{atm}}$ and $\Delta^{17} \mathrm{O}$ denote the $\Delta^{17} \mathrm{O}$ values of $222 \mathrm{NO}_{3}{ }^{-}$atm and nitrate (total) in the stream water sample, respectively. In this study, we 
used the average $\Delta^{17} \mathrm{O}$ value of $\mathrm{NO}_{3}{ }^{-}$atm determined at the nearby Sado-Seki monitoring station during the observation from April 2009 to March $2012\left(\Delta^{17} \mathrm{O}_{\mathrm{atm}}=+26.3 \%\right.$; Tsunogai et al., 2016) for $\Delta^{17} \mathrm{O}_{\text {atm }}$ in Eq. (2) to estimate $\left[\mathrm{NO}_{3}{ }^{-}{ }^{-}\right.$atm $]$in the stream. We allow for an error range in of $3 \%$ in $\Delta^{17} \mathrm{O}_{\mathrm{atm}}$, in which the factor changes in $\Delta^{17} \mathrm{O}_{\mathrm{atm}}$ from $+26.3 \%$ caused by both areal and seasonal variation in the $\Delta^{17} \mathrm{O}$ values of $\mathrm{NO}_{3}{ }^{-}$atm have been considered (Nakagawa et al., 2018; Tsunogai et al., 2016).

\section{Results}

3.1 Variation during the routine observation

During the routine observation, the concentrations of stream nitrate ranged from 35.7 $\mu \mathrm{M}$ to $129.3 \mu \mathrm{M}$ with the flux-weighted average concentration of $55.6 \mu \mathrm{M}$ (Fig. 2a), showing little temporal changes from that determined during the past observations from 2013 to 2014 at the same catchment (58.4 $\mu \mathrm{M}$; Nakagawa et al., 2018). The variation range also agreed with the past observation done in the same catchment (Kamisako et al., 2008), except for the extraordinarily large concentration (129.3 $\mu \mathrm{M})$ recorded on $2018 / 8 / 31$, which exceeded the $2 \sigma$ of the whole variation range of stream nitrate of our routine observation (Fig. 2a). We will discuss the reason in section 4.1.

The stable isotopic compositions of stream nitrate during the routine observation ranged from $+0.1 \%$ to $+5.9 \%$ for $\delta^{15} \mathrm{~N}$ (Fig. $2 \mathrm{~b}$ ), from $-1.9 \%$ to $+7.7 \%$ for $\delta^{18} \mathrm{O}$ (Fig. $2 \mathrm{c}$ ), and from $+0.4 \%$ to $+2.7 \%$ or $\Delta^{17} \mathrm{O}$ (Fig. $2 \mathrm{~d}$ ), while showing little seasonal variation. The flux-weighted averages for the $\delta^{15} \mathrm{~N}, \delta^{18} \mathrm{O}$, and $\Delta^{17} \mathrm{O}$ values of nitrate 
https://doi.org/10.5194/bg-2022-30

Preprint. Discussion started: 1 March 2022

(C) Author(s) 2022. CC BY 4.0 License.

(c) (i)

244 were $+2.0 \%,+1.1 \%$, and $+1.1 \%$, respectively. Except for the extraordinarily large

$245 \delta^{18} \mathrm{O}$ and $\Delta^{17} \mathrm{O}$ values we found on $2019 / 1 / 31\left(\delta^{18} \mathrm{O}=+7.7 \%\right.$ and $\Delta^{17} \mathrm{O}=+2.7 \%$ o $)$

246 (Figs. 2c and 2d), the values are typical for stream nitrate eluted from temperate forested

247 catchments (Hattori et al., 2019; Huang et al., 2020; Nakagawa et al., 2013, 2018; Riha

248 et al., 2014; Sabo et al., 2016; Tsunogai et al., 2014, 2016). On the other hand, the data

249 recorded on $2019 / 1 / 31$ exceeded the $2 \sigma$ variation range of the whole $\delta^{18} \mathrm{O}$ and $\Delta^{17} \mathrm{O}$

250 data. We will discuss the reason in section 4.2. 

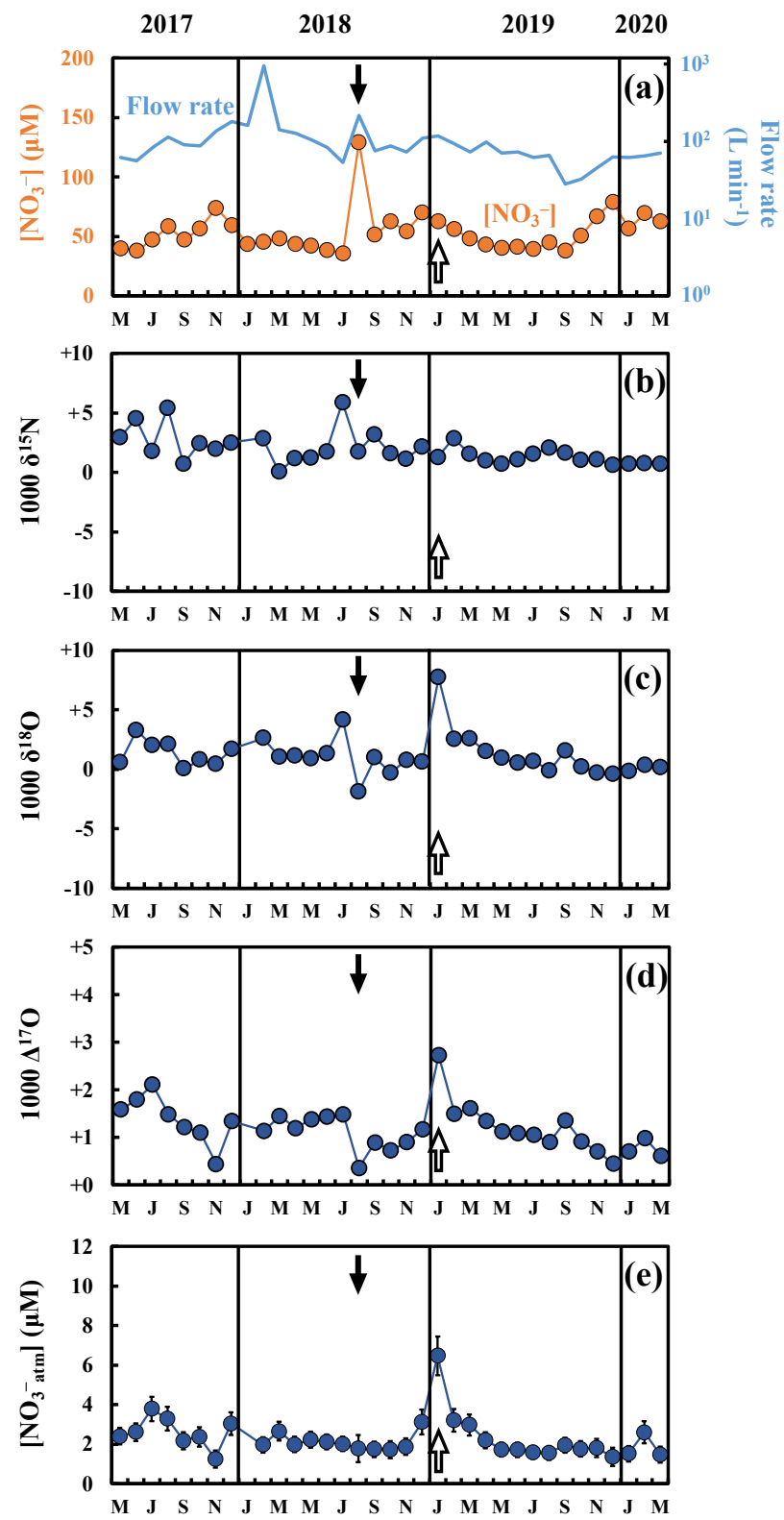

Figure 2. Temporal variations in the concentrations of nitrate (orange circles) and the

253 flow rates (blue line) in the stream water during the routine observation (a), together with those of the values of $\delta^{15} \mathrm{~N}(\mathrm{~b}), \delta^{18} \mathrm{O}(\mathrm{c}), \Delta^{17} \mathrm{O}(\mathrm{d})$ of nitrate, and the concentrations 
255 of unprocessed atmospheric nitrate $\left(\left[\mathrm{NO}_{3}{ }^{-}{ }_{\mathrm{atm}}\right]\right)(\mathrm{e})$ in the stream water (blue circles).

256 The black and white arrows in the figures indicate the sampling that took place on

257

258

259

260

261

262

263

264

3.2 Variation in response to the storm events

During the intensive observations made in response to the storm events, the concentration of stream nitrate showed significant short-term variation, from $24.7 \mu \mathrm{M}$ to $122.6 \mu \mathrm{M}$, from $28.7 \mu \mathrm{M}$ to $134.1 \mu \mathrm{M}$, and from $46.6 \mu \mathrm{M}$ to $114.5 \mu \mathrm{M}$ during the storm events I, II, and III, respectively, with the minimum recorded just before the beginning of each storm event and the maximum recorded when the flow rate was close to the maximum within each storm event (Figs. 3 and S1). The pattern and range of the short-term variation of the stream nitrate concentration during the three storm events were consistent with the past study done in the same catchment (Kamisako et al., 2008).

The stable isotopic compositions of stream nitrate during the three storm events also showed significant temporal variation, from $-0.1 \%$ to $+2.5 \%$, from $-0.5 \%$ o to $+3.0 \%$, and from $-0.1 \%$ to $+3.5 \%$ for $\delta^{15} \mathrm{~N}$ (Figs. $3 \mathrm{~b}, \mathrm{~S} 1 \mathrm{~b}$, and $\mathrm{S} 1 \mathrm{~g}$ ), from $-3.4 \%$ to $+3.1 \%$, from $-2.5 \%$ to $+2.9 \%$, and from $-2.3 \%$ to $+2.1 \%$ for $\delta^{18} \mathrm{O}$ (Figs. $3 \mathrm{c}, \mathrm{S} 1 \mathrm{c}$, and S1h), and from $+0.3 \%$ o to $+1.6 \%$, from $+0.3 \%$ to $+1.4 \%$, and from $+0.5 \%$ o to $+1.2 \%$ for $\Delta^{17} \mathrm{O}$ (Figs. 3d, S1d, and S1i), with minimum values observed when the concentration of stream nitrate was at maximum and maximum values observed when the 

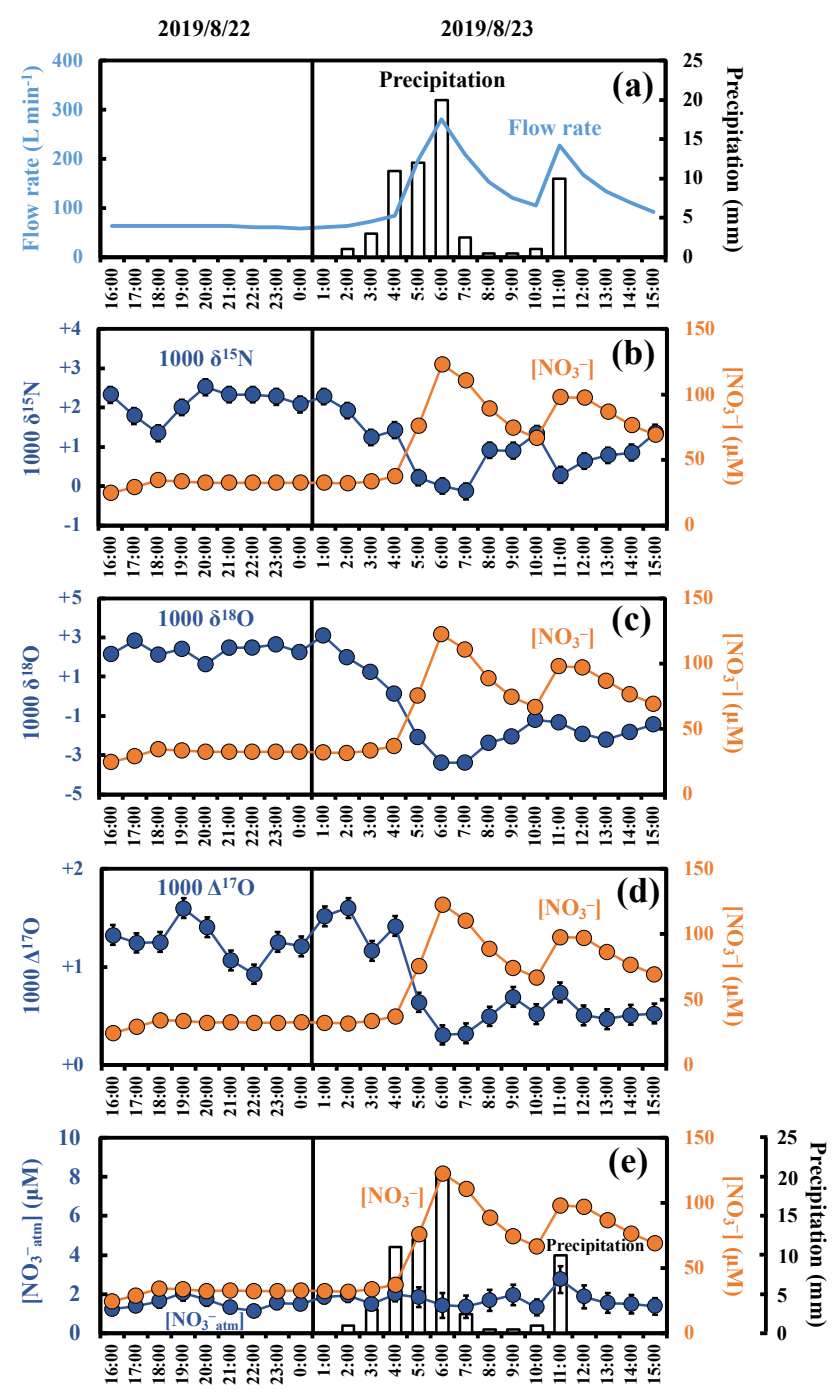

278 Figure. 3 Temporal variations in the precipitation (bar chart) and flow rates (blue line)

279 of the stream water during storm events I (a), together with those in the concentrations 


\section{Discussion}

4.1 Primary source of nitrate increased during storm events

The striking feature of the observed short-term variation was that all the stable isotopic compositions $\left(\delta^{15} \mathrm{~N}, \delta^{18} \mathrm{O}\right.$, and $\left.\Delta^{17} \mathrm{O}\right)$ varied in response to the variation in the nitrate concentration throughout the three storm events (Figs. 3 and S1). The result implied that the source of increased nitrate during the storm events were different from that during the base flow period.

The stable isotopic compositions $\left(\delta^{15} \mathrm{~N}, \delta^{18} \mathrm{O}\right.$, and $\left.\Delta^{17} \mathrm{O}\right)$ of stream nitrate were plotted as the functions of the reciprocal of the stream nitrate concentration $\left(1 /\left[\mathrm{NO}_{3}{ }^{-}\right]\right)$ for each storm event (Fig. 4). All the stable isotopic compositions of stream nitrate $\left(\delta^{15} \mathrm{~N}, \delta^{18} \mathrm{O}\right.$, and $\left.\Delta^{17} \mathrm{O}\right)$ showed strong linear relationships $\left(R^{2}>0.5 ; p<0.001\right)$ with the reciprocal of concentrations. The linear relationships strongly suggest mixing between two endmembers with distinctively different isotopic signatures (e.g. Keeling, 1958). The nitrate-depleted endmember must be the source of stream nitrate during the base flow period prior to each storm event. On the other hand, the nitrateenriched endmember represents the source of nitrate that was added during the storm events.

$$
\text { Atmospheric nitrate }\left(\mathrm{NO}_{3}{ }^{-} \text {atm }\right) \text { dissolved in rainwater was one of the possible }
$$
sources of nitrate enriched during the storm events (Kaushal et al., 2011; Sebestyen et 
al., 2014). While the $\mathrm{NO}_{3}{ }^{-}$atm showed the $\delta^{18} \mathrm{O}$ and $\Delta^{17} \mathrm{O}$ values enriched in both ${ }^{18} \mathrm{O}$ and ${ }^{17} \mathrm{O}$, more than $+55 \%$ and more than $+18 \%$, respectively, during summer periods in Japan (Tsunogai et al., 2016), the nitrate-enriched endmember showed the $\delta^{18} \mathrm{O}$ and $\Delta^{17} \mathrm{O}$ values depleted in both ${ }^{18} \mathrm{O}$ and ${ }^{17} \mathrm{O}$, less than $+3.1 \%$ and $+1.6 \%$, respectively, during the storm events. The concentrations of $\mathrm{NO}_{3}{ }^{-}$atm $\left(\left[\mathrm{NO}_{3}{ }^{-} \mathrm{atm}\right]\right)$ showed little temporal variations showing the concentrations of $1.6 \pm 0.4 \mu \mathrm{M}, 1.8 \pm$ $0.4 \mu \mathrm{M}$, and $2.1 \pm 0.4 \mu \mathrm{M}$ during the storm events I, II, and III, respectively (Figs. 3e, $\mathrm{S} 1 \mathrm{e}$, and $\mathrm{S} 1 \mathrm{j})$. In general, the $\left[\mathrm{NO}_{3}{ }^{-}\right.$atm $]$in rainwater were much higher than those in stream water (Nakagawa et al., 2018; Rose et al., 2015; Tsunogai et al., 2014). During the storm events I, II, and III, however, the $\left[\mathrm{NO}_{3}{ }^{-}\right.$atm $]$in stream water was almost constant irrespective to the increase in precipitation (Figs. 3e, S1e, and S1j). Thus, we conclude that the direct input of $\left[\mathrm{NO}_{3}{ }^{-}\right.$atm $]$via rainwater into the stream through overland flow during storm events can be negligible, at least in the KJ catchment.

Thus, we concluded that the $\mathrm{NO}_{3}{ }^{-}$atm should be the minor source of nitrate that increased during the storm events.

Nakagawa et al. (2018) determined the temporal variations in the concentrations (Fig. 5a) and isotopic compositions $\left(\delta^{15} \mathrm{~N}, \delta^{18} \mathrm{O}\right.$, and $\left.\Delta^{17} \mathrm{O}\right)$ (Figs. 5b, 5c, and 5d) of soil nitrate dissolved in soil water taken within the same catchment during 2013 to 2014, at the depths of $20 \mathrm{~cm}$ and $60 \mathrm{~cm}$ of the station SLS (SLS 20 and SLS 60, respectively) and at the depth of $20 \mathrm{~cm}$ of the station SMS (SMS 20), where the station SLS was located in the riparian zone of the stream and the station SMS was 
about $20 \mathrm{~m}$ away from the stream and located in the upland zone (Fig. 1b). The concentrations of soil nitrate showed significant seasonal variation, with the higher concentration in summer and the lower concentration in winter (Fig. 5a). Both the $\delta^{18} \mathrm{O}$ and $\Delta^{17} \mathrm{O}$ values also showed significant seasonal variation, with the minimum in summer and the maximum in winter (Figs. 5c and d). To verify if the soil nitrate is the source of the stream nitrate that was added to the stream during the storm events, we also plotted soil nitrate at each site (SLS 20, SLS 60 and SMS 20) of the same season in Fig. 4. Because our intensive observations on the storm events were done in summer (from August to October), the average concentration and the average isotopic composition during summer (from August to October) were calculated (Table 1) and plotted in Fig. 4. The error bars of each soil nitrate denote the standard deviation (SD) of each isotopic composition ( $\mathrm{n}=5$ for each). We found that the isotopic compositions $\left(\delta^{15} \mathrm{~N}, \delta^{18} \mathrm{O}\right.$, and $\left.\Delta^{17} \mathrm{O}\right)$ of soil nitrate in the riparian zone (SLS 20 and SLS 60; Table 1) were always plotted on the nitrate-enriched extension (lower $1 /\left[\mathrm{NO}_{3}{ }^{-}\right]$extension) of the mixing line during the storm events I, II, and III (Fig. 4), while those of the soil nitrate in the upland zone (SMS 20; Table 1) were somewhat deviated from the nitrate-enriched extension of the mixing line, $\delta^{18} \mathrm{O}$ especially (Figs. $4 \mathrm{~d}, 4 \mathrm{e}$, and $4 \mathrm{f}$ ). We conclude that the primary source of nitrate added during the storm events was the soil nitrate in the riparian zone.

$$
\text { The "flushing hypothesis" has been proposed to explain the increase in stream }
$$
nitrate concentration in accordance with the increase in flow rate during storm events 
345 (Creed et al., 1996; Hornberger et al., 1994). During the base flow periods, nitrate

346 accumulate in shallow, oxic soil layers due to the progress of nitrification. When

347 water level became higher during storm periods, concentration of stream nitrate

348 increased due to flushing of the soil nitrate accumulated in the shallow soil layers of riparian zones into stream (Chen et al., 2020; Creed et al., 1996; Ocampo et al., 2006).

Our finding that the primary source of nitrate increased during the storm events was the soil nitrate in the riparian zone is consistent with the "flushing hypothesis." We conclude that the flushing of soil nitrate in the riparian zone into the stream due to rising of both stream water and groundwater level was responsible for the increase in stream nitrate during the storm events (Fig. 6).

Within the whole dataset on the variation of the concentration of nitrate in the stream determined by Kamisako et al. (2008), an increase in the concentration of nitrate in the stream of more than $20 \mu \mathrm{M}$ in response to storm events was found to be limited to the storm events that occurred in the warm seasons, from June to November. As the concentrations of soil nitrate in the riparian zone (SLS 20 and SLS 60) were much higher in the warm seasons (734 $\mu \mathrm{M} \pm 496 \mu \mathrm{M}$; from June to November) than in the cold seasons $(156 \pm 124 \mu \mathrm{M}$; from December to May), such seasonal variation in the concentration of riparian soil nitrate is consistent with the observed seasonality in the influence of storm events on the stream nitrate concentration, where significant effects are observed during warm months, whereas insignificant effects are observed during cold months. 
https://doi.org/10.5194/bg-2022-30

Preprint. Discussion started: 1 March 2022

(c) Author(s) 2022. CC BY 4.0 License.

As mentioned in section 3.1, we found significant increase in nitrate concentration

up to $129.3 \mu \mathrm{M}$ on $2018 / 8 / 31$ during our routine observation on the stream, when the increase in flow rate (from $53.4 \mathrm{~L} /$ min one month before to $216.9 \mathrm{~L} / \mathrm{min}$ during sampling). The measured $\delta^{18} \mathrm{O}$ and $\Delta^{17} \mathrm{O}$ value of the stream nitrate on $2018 / 8 / 31$ $(-1.9 \%$ and $+0.4 \%$, respectively) showing significantly smaller values than those during the other routine observation (Fig. $2 \mathrm{c}$ and $2 \mathrm{~d}$ ), agreed well with those of the nitrate increase during the storm events I, II, and III. Moreover, both the range of increase in stream nitrate concentration $(129.3 \mu \mathrm{M})$ and the season of observation (August) also agreed well with those of the stream nitrate increase during the three storm events. As a result, we conclude that the input of soil nitrate accumulated in the riparian zone due to flushing was also responsible for the significant increase in stream nitrate concentration we found on 2018/8/31 during the routine observation. 

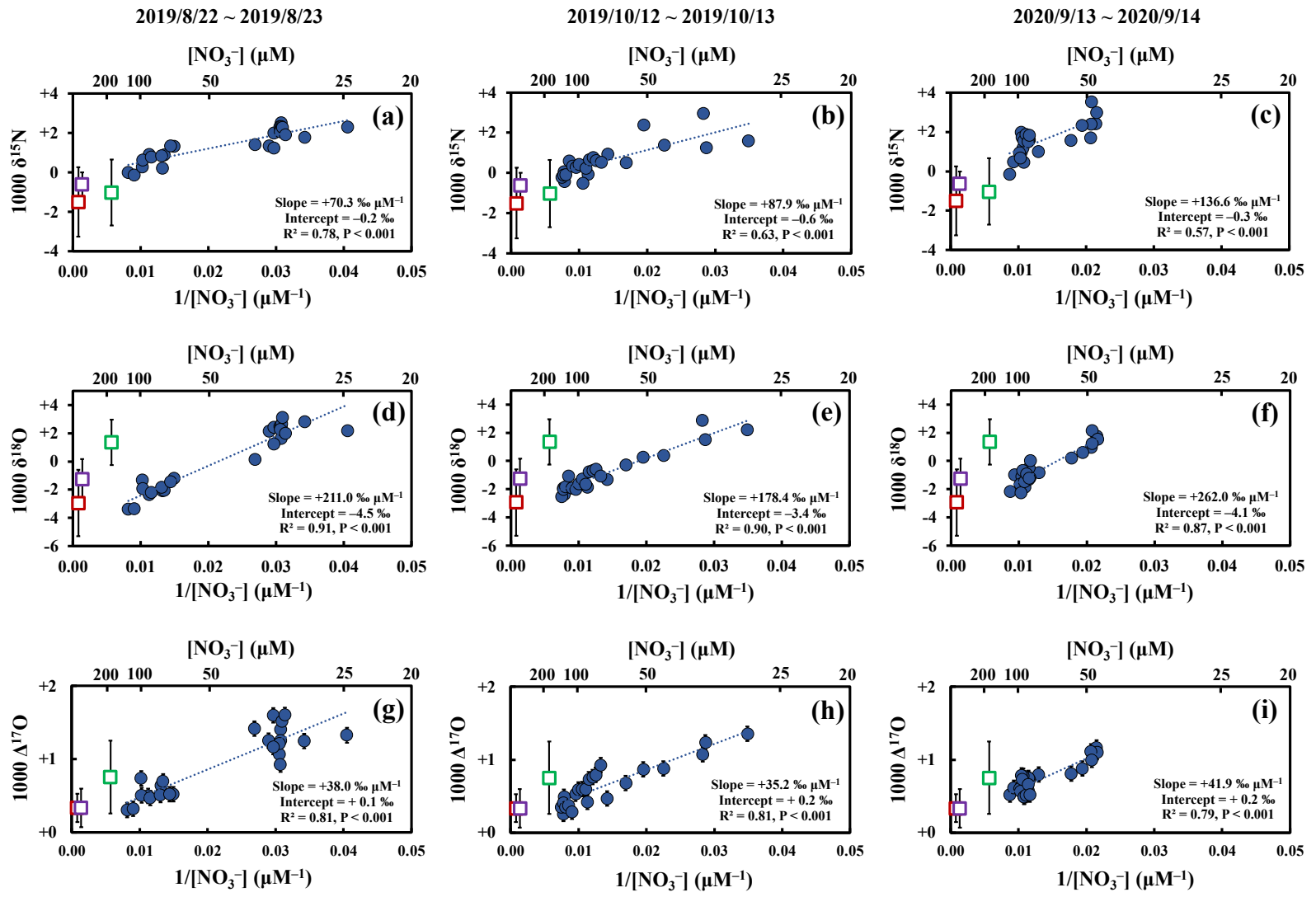

387 Figure 4. The $\delta^{15} \mathrm{~N}(\mathrm{a}, \mathrm{b}$, and $\mathrm{c}), \delta^{18} \mathrm{O}(\mathrm{d}, \mathrm{e}$, and $\mathrm{f})$, and $\Delta^{17} \mathrm{O}(\mathrm{g}, \mathrm{h}$, and $\mathrm{i})$ values of

388 stream nitrate (blue circles) during storm events I, II, and III plotted as a function of the

389 reciprocal of nitrate concentration $\left(1 /\left[\mathrm{NO}_{3}{ }^{-}\right]\right)$, together with those of soil nitrate at SLS

39020 (red squares), SLS 60 (purple squares), and SMS 20 (green squares) during August

391 to October in 2013 and 2014. The error bars of each soil nitrate denote the standard

392 deviation (SD) of each isotopic composition ( $\mathrm{n}=5$ for each). The error bars smaller than

393 the sizes of the symbols are not presented. 

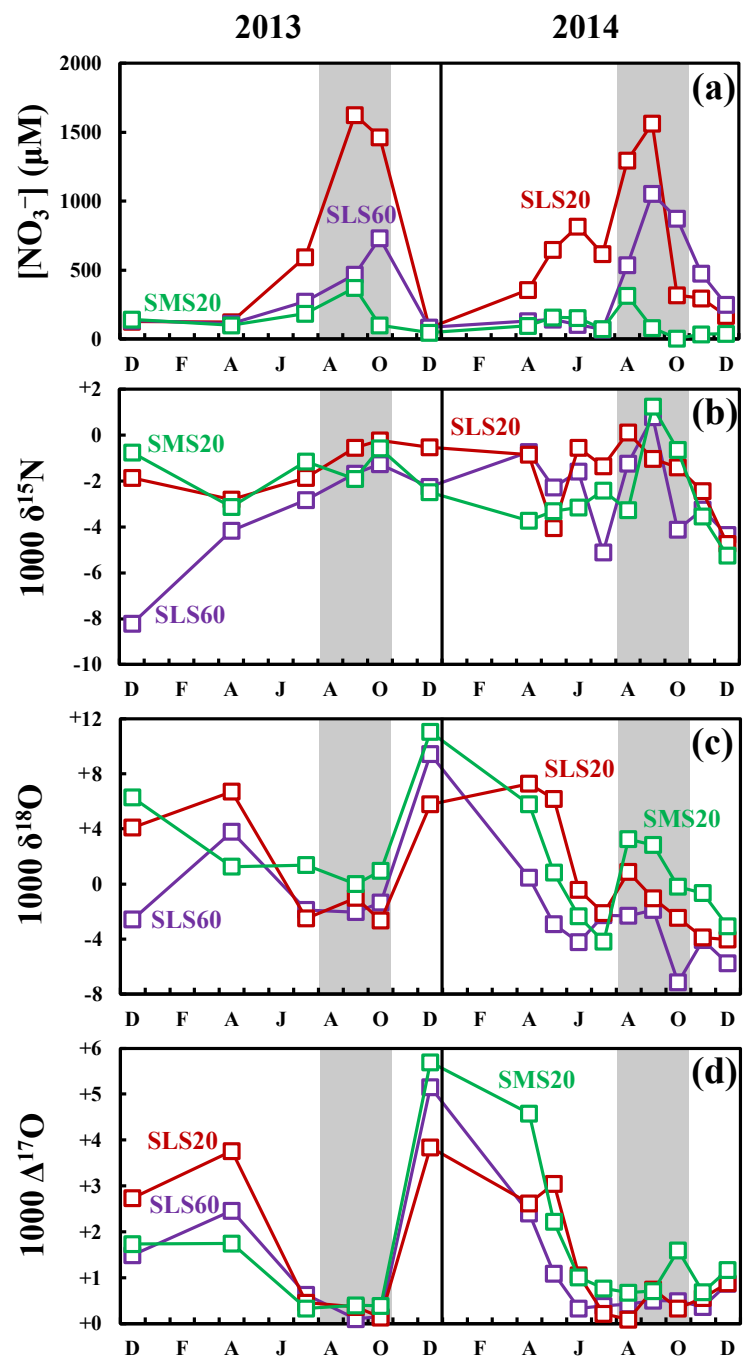

395 Figure 5. Seasonal variations in the concentrations of soil nitrate (a) at SLS 20 (red

396 squares), SLS 60 (purple squares), and SMS20 (green squares), together with those in

397 the values of $\delta^{15} \mathrm{~N}(\mathrm{~b}), \delta^{18} \mathrm{O}(\mathrm{c})$ and $\Delta^{17} \mathrm{O}$ (d) of each soil nitrate during 2013 to 2014

398 (modified from Nakagawa et al., 2018). The periods used to estimate the isotopic

399 compositions (from August to October) are presented in gray. The error bars were

400 smaller than the sizes of the symbols. 
401 Table 1 Concentrations and isotopic compositions $\left(\delta^{15} \mathrm{~N}, \delta^{18} \mathrm{O}\right.$, and $\left.\Delta^{17} \mathrm{O}\right)$ of soil nitrate

402 at SLS 20, SLS 60, and SMS 20 during August to October in 2013 and 2014

403 (recalculated from the data in Nakagawa et al., 2018).

\begin{tabular}{cccc}
\hline & SLS 20 & SLS 60 & SMS 20 \\
\hline $\mathrm{NO}_{3}{ }^{-}(\mu \mathrm{M})$ & $1254 \pm 537$ & $734 \pm 241$ & $176 \pm 159$ \\
$1000 \delta^{15} \mathrm{~N}$ & $-1.5 \pm 1.8$ & $-0.6 \pm 0.6$ & $-1.0 \pm 1.7$ \\
$1000 \delta^{18} \mathrm{O}$ & $-2.9 \pm 2.4$ & $-1.3 \pm 1.4$ & $+1.4 \pm 1.6$ \\
$1000 \Delta^{17} \mathrm{O}$ & $+0.3 \pm 0.2$ & $+0.3 \pm 0.3$ & $+0.8 \pm 0.5$ \\
\hline
\end{tabular}

407

(a)

Soil nitrate in the riparian zone (SLS20, SLS60)

Soil nitrate in the upland zone (SMS20)

Stream nitrate in base flow

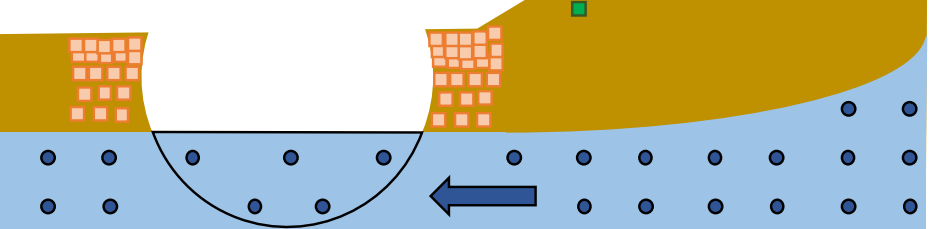

(b)

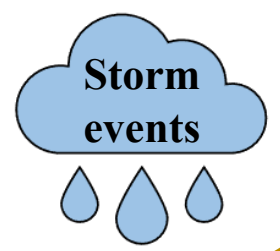

Soil nitrate in the riparian zone (SLS20, SLS60)

Soil nitrate in the upland zone (SMS20)

Stream nitrate in base flow

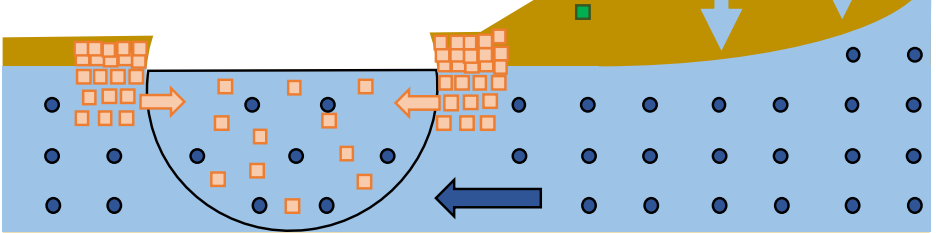


408 Figure 6. Schematic diagram showing the elution of soil nitrate to the stream before the storm events (a) and during the storm events (b). Soil nitrate in the riparian zone and that in the upland zone are represented by the orange squares and green squares,

411 respectively, while stream nitrate during base flow is represented by the blue circles. $\mu \mathrm{M}$ to $3.8 \mu \mathrm{M}$ during our routine observation in this study (Fig. 2e), except for the extraordinarily large $\left[\mathrm{NO}_{3}{ }^{-}\right.$atm $]$we found on $2019 / 1 / 31(6.5 \mu \mathrm{M})$. Except for the extraordinarily large $\left[\mathrm{NO}_{3}{ }^{-}\right.$atm $]$, the obtained $\left[\mathrm{NO}_{3}{ }^{-}{ }^{-}\right.$atm $]$corresponded well with those determined in the past study done at the same catchment (Nakagawa et al., 2018). In addition, they corresponded well with those of the temperate forested catchments saturated in nitrogen, such as Qingyuan Forest (2.0 $\mu \mathrm{M}$; Huang et al., 2020) and Fernow experimental Forest 1, 2, and $3(1.6 \mu \mathrm{M}, 3.4 \mu \mathrm{M}$, and $4.2 \mu \mathrm{M}$, respectively; Rose et al., 2015).

In this study, accumulation of snow was observed at the KJ catchment on 2019/1/27, of up to $18 \mathrm{~cm}$, while most of the accumulated snow had melted to a depth of $1 \mathrm{~cm}$ during the routine observation period from $2017 / 5$ to $2020 / 3$, no other snow-melting events were experienced within 4 days prior to the sampling day, except for the sampling on 2019/1/31. Similar enhancement in the concentration of $\mathrm{NO}_{3}{ }^{-}$atm, as well 
429 as the $\delta^{18} \mathrm{O}$ and $\Delta^{17} \mathrm{O}$ of stream nitrate, in response to snow melting has been frequently 430 observed in streams worldwide (Ohte et al., 2004, 2010; Pellerin et al., 2012; Piatek et 431 al., 2005; Rose et al., 2015; Sabo et al., 2016; Tsunogai et al., 2014, 2016). We conclude 432 that input of the $\mathrm{NO}_{3}{ }^{-}$atm accumulated in the melted snow water, showing $\delta^{18} \mathrm{O}$ and $\Delta^{17} \mathrm{O}$ values significantly higher than those in the stream, caused the extraordinarily increase in $\left[\mathrm{NO}_{3}{ }^{-}\right.$atm $]$on $2019 / 1 / 31$. Except for the extraordinarily increase in $\left[\mathrm{NO}_{3}{ }^{-} \mathrm{atm}\right](\mathrm{n}=1)$, $\left[\mathrm{NO}_{3}{ }^{-}{ }^{-}\right.$atm $]$was stable at $2.2 \pm 0.6 \mu \mathrm{M}$ throughout the routine observation $(\mathrm{n}=33)$. We concluded that $\left[\mathrm{NO}_{3}{ }^{-}\right.$atm $]$was generally stable in the stream.

\subsection{The impact of storm events on the index of the nitrogen saturation}

The concentration of stream nitrate eluted from a forested catchment has been used as an index to evaluate the stage of nitrogen saturation in the forest (Huang et al., 2020; Rose et al., 2015; Stoddard, 1994). However, McHale et al. (2002) pointed out the problem in the reliability of this index, because the number of storm events influenced the concentration of nitrate eluted from forested stream significantly. That is, if we use the concentration of stream nitrate sampled during the storm events to evaluate the stage of nitrogen saturation in a forested catchment, the stage of nitrogen saturation might be overestimated.

Nakagawa et al. (2018) have proposed the export flux of $\mathrm{NO}_{3}{ }^{-}$atm $\left(\mathrm{M}_{\mathrm{atm}}\right)$ relative to the deposition flux of $\mathrm{NO}_{3}{ }^{-}$atm $\left(\mathrm{D}_{\mathrm{atm}}\right)$ can be an alternative, more robust index for nitrogen saturation in temperate forested catchments. To estimate reliable $\mathrm{M}_{\mathrm{atm}}$ in each 
450 forested catchment, we must obtain reliable $\left[\mathrm{NO}_{3}{ }^{-}{ }^{-}\right.$] $]$in the forested stream, including

their temporal variation. While the past studies focused on the seasonal variation of concentration and export flux of $\mathrm{NO}_{3}{ }^{-}$atm in forested streams (Hattori et al., 2019; had little knowledge on the variation of $\left[\mathrm{NO}_{3}{ }^{-}\right.$atm $]$in response to the increase in nitrate concentration during storm events prior to this study. constant irrespective to the significant variation in $\left[\mathrm{NO}_{3}^{-}\right]$during storm events (Figs. $\left[\mathrm{NO}_{3}{ }^{-}\right.$atm $]$remained almost constant as well, while $\left[\mathrm{NO}_{3}{ }^{-}\right]$increased from $35.7 \mu \mathrm{M}(1$ month before) to $129.3 \mu \mathrm{M}$ (Fig. 2e). The observed $\left[\mathrm{NO}_{3}{ }^{-}\right.$atm $]$showing almost constant values implies that the primary source of $\mathrm{NO}_{3}{ }^{-}$atm in stream water during storm events was the $\mathrm{NO}_{3}{ }^{-}$atm stored in groundwater, which is the same source as that during the base flow periods, rather than the direct input of $\mathrm{NO}_{3}{ }^{-}$atm from rainwater through overland flow. Hence, on the basis of the data of the annual average flow rate of the stream from the catchment, a reliable annual $\mathrm{M}_{\mathrm{atm}}$ can be estimated from $\left[\mathrm{NO}_{3}{ }^{-}{ }^{-}\right.$atm $]$, even if the $\left[\mathrm{NO}_{3}{ }^{-}\right.$atm $]$data during storm events is included. While the annual $\mathrm{M}_{\mathrm{atm}}$ could increase in response to the increase in the number of storm events because of the increase in the flow rate, the annual $D_{\text {atm }}$ also increases in response to the increase in the number of storm events. Consequently, it can be concluded that storm events have little impact on the $\mathrm{M}_{\mathrm{atm}} / \mathrm{D}_{\mathrm{atm}}$. As long as $\mathrm{NO}_{3}{ }^{-}$atm experiences the metabolized processes (uptake or 
472 correctly reflect the total demand on $\mathrm{NO}_{3}{ }^{-}$atm in each forested catchment and thus the

473 nitrogen saturation status. We conclude that the $\mathrm{M}_{\mathrm{atm}} / \mathrm{D}_{\mathrm{atm}}$ ration can be used as the

474 robust index to evaluate nitrogen saturation in forested catchments, on which storm

475 events have little influence.

\section{Conclusions}

478 Temporal variation in the concentrations and stable isotopic compositions $\left(\delta^{15} \mathrm{~N}\right.$,

$479 \delta^{18} \mathrm{O}$, and $\Delta^{17} \mathrm{O}$ ) of stream nitrate were determined during storm events to clarify the

480 source of stream nitrate increased during storm events. Because the stable isotopic

481 compositions of soil nitrate in riparian zone during summer agreed well with those of the nitrate-enrich endmember of the stream nitrate during storm events, we conclude that the soil nitrate in riparian zone was responsible for the stream nitrate increased during storm events. Additionally, the concentration of $\mathrm{NO}_{3}{ }^{-}$atm in stream was almost constant during the storm events, implied that the source of $\mathrm{NO}_{3}{ }^{-}$atm in stream water during storm events was the $\mathrm{NO}_{3}{ }^{-}$atm stored in groundwater. We concluded that the number of storm events have little impact on $\mathrm{M}_{\mathrm{atm}} / \mathrm{D}_{\mathrm{atm}}$ ratio, the index of nitrogen saturation. In addition, the $\Delta^{17} \mathrm{O}$ of nitrate can be applicable as the tracer to clarify the source of nitrate. 
are available upon request to the corresponding author (Weitian Ding).

493

494 Author contributions. WD, UT, NY, and HS designed the study. HY, MM, and HS

495 performed the field observations. HY, MM, and HS determined the concentrations of the samples. WD determined the isotopic compositions of the samples. WD, TS, FN, and UT performed data analysis, and WD and UT wrote the paper with input from MM, HY and HS.

499

Competing interests. The authors declare that they have no conflict of interest.

Acknowledgements. the Environment in Japan. The authors are grateful to Ryo Shingubara, Masanori Ito,

510 Sports, Science, and Technology of Japan under grant numbers JP17H00780,

511 JP19H04254, and JP19H00955 and by the Yanmar Environmental Sustainability

512 Support Association. 


\section{Reference}

515 Aber, J. D., Nadelhoffer, K. J., Steudler, P. and Melillo, J. M.: Nitrogen Saturation in

516 Northern Forest Ecosystems, Bioscience, 39(6), 378-386, doi:10.2307/1311067, 5171989.

518 Aguilera, R. and Melack, J. M.: Concentration-Discharge Responses to Storm Events

519 in Coastal California Watersheds, Water Resour. Res., 54(1), 407-424,

520 doi:10.1002/2017WR021578, 2018.

521 Alexander, B., Hastings, M. G., Allman, D. J., Dachs, J., Thornton, J. A. and

523 global model of the oxygen isotopic composition $\left(\delta^{17} \mathrm{O}\right)$ of atmospheric nitrate,

524 Atmos. Chem. Phys., 9(14), 5043-5056, doi:10.5194/acp-9-5043-2009, 2009.

525 Burns, D. A. and Kendall, C.: Analysis of $\delta^{15} \mathrm{~N}$ and $\delta^{18} \mathrm{O}$ to differentiate $\mathrm{NO}_{3}{ }^{-}$sources

526 in runoff at two watersheds in the Catskill Mountains of New York, Water Resour.

527 Res., 38(5), 91-912, doi:10.1029/2001wr000292, 2002.

528 Chen, X., Tague, C. L., Melack, J. M. and Keller, A. A.: Sensitivity of nitrate

529 concentration-discharge patterns to soil nitrate distribution and drainage properties in

530 the vertical dimension, Hydrol. Process., 34(11), 2477-2493, doi:10.1002/hyp.13742,

5312020.

532 Creed, I. F., Band, L. E., Foster, N. W., Morrison, I. K., Nicolson, J. A., Semkin, R. S.

533 and Jeffries, D. S.: Regulation of nitrate-N release from temperate forests: A test of 
https://doi.org/10.5194/bg-2022-30

Preprint. Discussion started: 1 March 2022

(c) Author(s) 2022. CC BY 4.0 License.

534 the N flushing hypothesis, Water Resour. Res., 32(11), 3337-3354,

535 doi:10.1029/96WR02399, 1996.

536 Durka, W., Schulze, E., Gebauer, G. and Voerkeliust, S.: Effects of forest decline on

537 uptake and leaching of deposited nitrate determined from ${ }^{15} \mathrm{~N}$ and ${ }^{18} \mathrm{O}$ measurements,

538 Nature, 372, 765-767, doi: https://doi.org/10.1038/372765a0, 1994.

539 Galloway, J. N., Aber, J. D., Erisman, J. W., Seitzinger, S. P., Howarth, R. W.,

540 Cowling, E. B. and Cosby, B. J.: The nitrogen cascade, Bioscience, 53(4), 341-356,

541 doi:10.1641/0006-3568(2003)053[0341:TNC]2.0.CO;2, 2003.

542 Hattori, S., Nuñez Palma, Y., Itoh, Y., Kawasaki, M., Fujihara, Y., Takase, K. and

543 Yoshida, N.: Isotopic evidence for seasonality of microbial internal nitrogen cycles in

544 a temperate forested catchment with heavy snowfall, Sci. Total Environ., 690, 290-

$545 \quad$ 299, doi:10.1016/j.scitotenv.2019.06.507, 2019.

546 Hirota, A., Tsunogai, U., Komatsu, D. D. and Nakagawa, F.: Simultaneous

547 determination of $\delta^{15} \mathrm{~N}$ and $\delta^{18} \mathrm{O}$ of $\mathrm{N}_{2} \mathrm{O}$ and $\delta^{13} \mathrm{C}$ of $\mathrm{CH}_{4}$ in nanomolar quantities from

548 a single water sample, Rapid Commun. Mass Spectrom., 24, 1085-1092,

549 doi:10.1002/rcm.4483, 2010.

550 Hornberger, G. M., Bencala, K. E. and McKnight, D. M.: Hydrological controls on

551 dissolved organic carbon during snowmelt in the Snake River near Montezuma,

552 Colorado, Biogeochemistry, 25(3), 147-165, doi:10.1007/BF00024390, 1994.

553 Huang, S., Wang, F., Elliott, E. M., Zhu, F., Zhu, W., Koba, K., Yu, Z., Hobbie, E.

554 A., Michalski, G., Kang, R., Wang, A., Zhu, J., Fu, S. and Fang, Y.: Multiyear 
555 Measurements on $\Delta^{17} \mathrm{O}$ of Stream Nitrate Indicate High Nitrate Production in a

556 Temperate Forest, Environ. Sci. Technol., 54(7), 4231-4239,

doi:10.1021/acs.est.9b07839, 2020.

558 Inoue, T., Nakagawa, F., Shibata, H. and Tsunogai, U.: Vertical Changes in the Flux of Atmospheric Nitrate From a Forest Canopy to the Surface Soil Based on $\Delta^{17} \mathrm{O}$ Values, J. Geophys. Res. Biogeosciences, 126(4), 1-18, doi:10.1029/2020JG005876, 2021.

Kaiser, J., Hastings, M. G., Houlton, B. Z., Röckmann, T. and Sigman, D. M.: Triple oxygen isotope analysis of nitrate using the denitrifier method and thermal decomposition of $\mathrm{N}_{2} \mathrm{O}$, Anal. Chem., 79(2), 599-607, doi:10.1021/ac061022s, 2007. Kamisako, M., Sase, H., Matsui, T., Suzuki, H., Takahashi, A., Oida, T., Nakata, M., Totsuka, T. and Ueda, H.: Seasonal and annual fluxes of inorganic constituents in a small catchment of a Japanese cedar forest near the sea of Japan, Water. Air. Soil Pollut., 195(1-4), 51-61, doi:10.1007/s11270-008-9726-8, 2008.

\section{Kaushal, S. S., Groffman, P. M., Band, L. E., Elliott, E. M., Shields, C. A. and}

Kendall, C.: Tracking nonpoint source nitrogen pollution in human-impacted watersheds, Environ. Sci. Technol., 45(19), 8225-8232, doi:10.1021/es200779e, 2011.

Keeling, D.: The concentration and isotopic abundances of atmospheric carbon dioxide in rural areas, Geochim. Cosmochim. Acta, 13, 322-334, doi:https://doi.org/10.1016/0016-7037(58)90033-4, 1958. 
https://doi.org/10.5194/bg-2022-30

Preprint. Discussion started: 1 March 2022

(c) Author(s) 2022. CC BY 4.0 License.

576 Kendall, C., Elliott, E. M. and Wankel, S. D.: Tracing Anthropogenic Inputs of

577 Nitrogen to Ecosystems, Stable Isot. Ecol. Environ. Sci. Second Ed., 375-449,

578 doi:10.1002/9780470691854.ch12, 2008.

579 Komatsu, D. D., Ishimura, T., Nakagawa, F. and Tsunogai, U.: Determination of the

$580{ }^{15} \mathrm{~N} /{ }^{14} \mathrm{~N},{ }^{17} \mathrm{O} /{ }^{16} \mathrm{O}$, and ${ }^{18} \mathrm{O} /{ }^{16} \mathrm{O}$ ratios of nitrous oxide by using continuous-flow

581 isotope-ratio mass spectrometry Daisuke, Rapid Commun. Mass Spectrom., 22, 1587-

$582 \quad$ 1596, doi:10.1002/rcm.3493, 2008.

583 Konno, U., Tsunogai, U., Komatsu, D. D., Daita, S., Nakagawa, F., Tsuda, A.,

584 Matsui, T., Eum, Y. J. and Suzuki, K.: Determination of total N2 fixation rates in the

585 ocean taking into account both the particulate and filtrate fractions, Biogeosciences,

586 7(8), 2369-2377, doi:10.5194/bg-7-2369-2010, 2010.

587 McHale, M. R., McDonnell, J. J., Mitchell, M. J. and Cirmo, C. P.: A field-based

588 study of soil water and groundwater nitrate release in an Adirondack forested

589 watershed, Water Resour. Res., 38(4), 2-1-2-16, doi:10.1029/2000wr000102, 2002.

590 Mcllvin, M. R. and Altabet, M. A.: Chemical conversion of nitrate and nitrite to

591 nitrous oxide for nitrogen and oxygen isotopic analysis in freshwater and seawater,

592 Anal. Chem., 77(17), 5589-5595, doi:10.1021/ac050528s, 2005.

593 Michalski, G., Scott, Z., Kabiling, M. and Thiemens, M. H.: First measurements and

594 modeling of $\Delta^{17} \mathrm{O}$ in atmospheric nitrate, Geophys. Res. Lett., 30(16), 3-6,

595 doi:10.1029/2003GL017015, 2003.

596 Michalski, G., Meixner, T., Fenn, M., Hernandez, L., Sirulnik, A., Allen, E. and 
https://doi.org/10.5194/bg-2022-30

Preprint. Discussion started: 1 March 2022

(c) Author(s) 2022. CC BY 4.0 License.

597 Thiemens, M.: Tracing Atmospheric Nitrate Deposition in a Complex Semiarid

598 Ecosystem Using $\Delta^{17}$ O, Environ. Sci. Technol., 38(7), 2175-2181,

599 doi:10.1021/es034980+, 2004.

600 Mitchell, M. J., Iwatsubo, G., Ohrui, K. and Nakagawa, Y.: Nitrogen saturation in

601 Japanese forests: An evaluation, For. Ecol. Manage., 97(1), 39-51,

602 doi:10.1016/S0378-1127(97)00047-9, 1997.

603

Morin, S., Sander, R. and Savarino, J.: Simulation of the diurnal variations of the

604 oxygen isotope anomaly $\left(\Delta^{17} \mathrm{O}\right)$ of reactive atmospheric species, Atmos. Chem. Phys.,

605

606

607

608

609

610

611

612

613

614

615

616

617

11(8), 3653-3671, doi:10.5194/acp-11-3653-2011, 2011.

Nakagawa, F., Suzuki, A., Daita, S., Ohyama, T., Komatsu, D. D. and Tsunogai, U.:

Tracing atmospheric nitrate in groundwater using triple oxygen isotopes: Evaluation

based on bottled drinking water, Biogeosciences, 10(6), 3547-3558, doi:10.5194/bg-

10-3547-2013, 2013.

Nakagawa, F., Tsunogai, U., Obata, Y., Ando, K., Yamashita, N., Saito, T.,

Uchiyama, S., Morohashi, M. and Sase, H.: Export flux of unprocessed atmospheric

nitrate from temperate forested catchments: A possible new index for nitrogen

saturation, Biogeosciences, 15(22), 7025-7042, doi:10.5194/bg-15-7025-2018, 2018.

Nelson, D. M., Tsunogai, U., Ding, D., Ohyama, T., Komatsu, D. D., Nakagawa, F., Noguchi, I. and Yamaguchi, T.: Triple oxygen isotopes indicate urbanization affects sources of nitrate in wet and dry atmospheric deposition, Atmos. Chem. Phys., 18(9), 6381-6392, doi:10.5194/acp-18-6381-2018, 2018. 
619 riparian zones in agricultural catchments: Implications for runoff generation and

620 nitrate transport, J. Hydrol., 331(3-4), 643-658, doi:10.1016/j.jhydrol.2006.06.010,

6212006.

Ohte, N., Sebestyen, S. D., Shanley, J. B., Doctor, D. H., Kendall, C., Wankel, S. D. and Boyer, E. W.: Tracing sources of nitrate in snowmelt runoff using a high-

624

625

626

627 resolution isotopic technique, Geophys. Res. Lett., 31(21), 2-5, doi:10.1029/2004GL020908, 2004.

Ohte, N., Tayasu, I., Kohzu, A., Yoshimizu, C., Osaka, K., Makabe, A., Koba, K., Yoshida, N. and Nagata, T.: Spatial distribution of nitrate sources of rivers in the lake Biwa Watershed, Japan: Controlling factors revealed by nitrogen and oxygen isotope values, Water Resour. Res., 46(7), 1-16, doi:10.1029/2009WR007871, 2010.

Paerl, H. W. and Huisman, J.: Climate change: A catalyst for global expansion of harmful cyanobacterial blooms, Environ. Microbiol. Rep., 1(1), 27-37, doi:10.1111/j.1758-2229.2008.00004.x, 2009.

Pellerin, B. A., Saraceno, J. F., Shanley, J. B., Sebestyen, S. D., Aiken, G. R., Wollheim, W. M. and Bergamaschi, B. A.: Taking the pulse of snowmelt: In situ sensors reveal seasonal, event and diurnal patterns of nitrate and dissolved organic matter variability in an upland forest stream, Biogeochemistry, 108(1-3), 183-198, doi:10.1007/s10533-011-9589-8, 2012.

Peterjohn, W. T., Adams, M. B. and Gilliam, F. S.: Symptoms of nitrogen saturation 
https://doi.org/10.5194/bg-2022-30

Preprint. Discussion started: 1 March 2022

(c) Author(s) 2022. CC BY 4.0 License.

639 in two central Appalachian hardwood forest ecosystems, Biogeochemistry, 35(3),

640 507-522, doi:10.1007/BF02183038, 1996.

641 Piatek, K. B., Mitchell, M. J., Silva, S. R. and Kendall, C.: Sources of nitrate in

642 snowmelt discharge: Evidence from water chemistry and stable isotopes of nitrate,

643 Water. Air. Soil Pollut., 165(1-4), 13-35, doi:10.1007/s11270-005-4641-8, 2005.

644 Riha, K. M., Michalski, G., Gallo, E. L., Lohse, K. A., Brooks, P. D. and Meixner, T.:

645 High Atmospheric Nitrate Inputs and Nitrogen Turnover in Semi-arid Urban

646 Catchments, Ecosystems, 17(8), 1309-1325, doi:10.1007/s10021-014-9797-x, 2014.

647 Rose, L. A., Elliott, E. M. and Adams, M. B.: Triple Nitrate Isotopes Indicate

648 Differing Nitrate Source Contributions to Streams Across a Nitrogen Saturation

649 Gradient, Ecosystems, 18(7), 1209-1223, doi:10.1007/s10021-015-9891-8, 2015.

650 Sabo, R. D., Nelson, D. M. and Eshleman, K. N.: Episodic, seasonal, and annual

651 export of atmospheric and microbial nitrate from a temperate forest, Geophys. Res.

652 Lett., 43(2), 683-691, doi:10.1002/2015GL066758, 2016.

653 Sase, H., Takahashi, A., Sato, M., Kobayashi, H., Nakata, M. and Totsuka, T.:

654 Seasonal variation in the atmospheric deposition of inorganic constituents and canopy

655 interactions in a Japanese cedar forest, Environ. Pollut., 152(1), 1-10,

656 doi:10.1016/j.envpol.2007.06.023, 2008.

657 Sase, H., Saito, T., Takahashi, M., Morohashi, M., Yamashita, N., Inomata, Y.,

658 Ohizumi, T. and Nakata, M.: Transboundary air pollution reduction rapidly reflected

659 in stream water chemistry in forested catchment on the Sea of Japan coast in central 
https://doi.org/10.5194/bg-2022-30

Preprint. Discussion started: 1 March 2022

(c) Author(s) 2022. CC BY 4.0 License.

660 Japan, Atmos. Environ., 248(November 2020), 118223,

661 doi:10.1016/j.atmosenv.2021.118223, 2021.

662 Sebestyen, S. D., Shanley, J. B., Boyer, E. W., Kendall, C. and Doctor., D. H.:

663 Coupled hydrological and biogeochemical processes controlling variability of

664 nitrogen species in streamflow during autumn in an upland forest, , 1569-1591,

665 doi:10.1002/2013WR013670, 2014.

666 Stoddard, J. L.: Long-Term Changes in Watershed Retention of Nitrogen, , 223-284, 667 doi:10.1021/ba-1994-0237.ch008, 1994.

668 Tsunogai, U., Komatsu, D. D., Daita, S., Kazemi, G. A., Nakagawa, F., Noguchi, I.

669 and Zhang, J.: Tracing the fate of atmospheric nitrate deposited onto a forest

670 ecosystem in Eastern Asia using $\Delta^{17} \mathrm{O}$, Atmos. Chem. Phys., 10(4), 1809-1820,

671 doi:10.5194/acp-10-1809-2010, 2010.

672 Tsunogai, U., Daita, S., Komatsu, D. D., Nakagawa, F. and Tanaka, A.: Quantifying

673 nitrate dynamics in an oligotrophic lake using $\Delta^{17} \mathrm{O}$, Biogeosciences, 8(3), 687-702,

674 doi:10.5194/bg-8-687-2011, 2011.

675 Tsunogai, U., Komatsu, D. D., Ohyama, T., Suzuki, A., Nakagawa, F., Noguchi, I.,

676 Takagi, K. and Nomura, M.: Quantifying the effects of clear-cutting and strip-cutting

677 on nitrate dynamics in a forested watershed using triple oxygen isotopes as tracers, ,

678 (1), 5411-5424, doi:10.5194/bg-11-5411-2014, 2014.

679 Tsunogai, U., Miyauchi, T., Ohyama, T., Komatsu, D. D., Nakagawa, F., Obata, Y.,

680 Sato, K. and Ohizumi, T.: Accurate and precise quantification of atmospheric nitrate 
https://doi.org/10.5194/bg-2022-30

Preprint. Discussion started: 1 March 2022

(c) Author(s) 2022. CC BY 4.0 License.

681 in streams draining land of various uses by using triple oxygen isotopes as tracers,

682 Biogeosciences, 13(11), 3441-3459, doi:10.5194/bg-13-3441-2016, 2016.

683 Tsunogai, U., Miyauchi, T., Ohyama, T., Komatsu, D. D., Ito, M. and Nakagawa, F.:

684 Quantifying nitrate dynamics in a mesotrophic lake using triple oxygen isotopes as

685 tracers, Limnol. Oceanogr., 63, S458-S476, doi:10.1002/lno.10775, 2018.

686 Vitousek, P. M. and Howarth, R. W.: Nitrogen limitation on land and in the sea: How

687 can it occur?, Biogeochemistry, 13(2), 87-115, doi:10.1007/BF00002772, 1991.

688 Yamazaki, A., Watanabe, T. and Tsunogai, U.: Nitrogen isotopes of organic nitrogen

689 in reef coral skeletons as a proxy of tropical nutrient dynamics, Geophys. Res. Lett.,

690 38(19), 1-5, doi:10.1029/2011GL049053, 2011. 